\title{
Are Medieval Mya arenaria (Mollusca; Bivalvia) in the Netherlands also clams before Columbus?
}

\section{K. Essink ${ }^{1, *}$, A.P. Oost ${ }^{2,3}$, H.J. Streurman ${ }^{4}$ \& J. Van der Plicht ${ }^{4,5}$}

\author{
1 Sunken History Foundation, Vosbergerlaan 14, NL-9761 AK Eelde, the Netherlands \\ 2 Deltares, P.0. Box 85467, NL-3508 AL Utrecht, the Netherlands \\ 3 Utrecht University, Department of Physical Geography, P.0. Box 80021, NL-3508 TA Utrecht, the Netherlands \\ 4 Centre for Isotope Research, Groningen University, Nijenborgh 4, NL-9747 AG Groningen, the Netherlands \\ 5 Faculty of Archaeology, Leiden University, Einsteinweg 2, NL-2333 CC Leiden, the Netherlands \\ * Corresponding author. Email: karelessink@hetnet.nl
}

Manuscript received: 11 May 2015, accepted: 15 April 2016

\section{Abstract}

During the Pleistocene, the coastal marine bivalve mollusc Mya arenaria became extinct in northwest Europe. The species remained present in North America. Datings of Mya shells found in northern Denmark and the southern Baltic Sea suggest that repopulation of northwest European coasts already occurred before Columbus' discovery of America (1492), possibly facilitated by Viking (Norse) settlers at Greenland and northeast North America. In this paper we report on findings of M. arenaria at five locations in the coastal landscape of the Netherlands: polders reclaimed from the Wadden Sea and the former estuaries of Oer-IJ and Old Rhine. The shells from four of these locations also date before 1492 AD.

Keywords: North America, North Sea, ${ }^{14} \mathrm{C}$ dating, pre-Columbus, Wadden Sea

\section{Introduction}

The coastal marine bivalve mollusc Mya arenaria is considered to have become extinct in northwest Europe during the (late) Pleistocene (Strasser, 1999; Lasota et al., 2004). The species remained present along the Atlantic coasts of North America. Van Benthem Jutting (1942), however, states that M. arenaria was present during several Holocene periods in the Netherlands. A re-introduction to European coasts did not occur for a long time. The species was not found in Stone Age kitchen middens ('køkkenmøddinger') around the North Sea and the Atlantic coast of France (Hessland, 1946; Petersen et al., 1992; Dupont et al., 2007, 2009), nor in a Bronze Age shell midden in Normandy (France) (Mougne et al., 2014). It didn't show up either in Roman and post-Roman middens (Dubois, 1924, in Bernard, 1979). In Rondeletius (1554) no description is given of a Mya-resembling bivalve among his listing of over 70 species from Gallia and Germania superior. The first record in Western Europe of a living specimen was reported in Belgium in 1583 (Raeymaekers, 1898, in Bernard, 1979). The oldest record of living $M$. arenaria in the Netherlands is from a creek in the southwest Netherlands (Baster, 1765). These records were considered the result of transport of the species by early (16th century) French colonisers of the North American Atlantic shores (Petersen et al., 1992). There are, however, finds of older $M$. arenaria shells at the Kattegat coast, northern Denmark (dated 1245-1295 AD by Petersen et al., 1992) and in the Greifswalder Bodden, southern Baltic Sea (dated $1310 \pm 70$ AD by Behrends et al., 2005). These finds, clearly predating Columbus' discovery of America in 1492, support the hypothesis by Petersen et al. (1992) of Viking-mediated transport of this species c. 200 years earlier. In this paper we report on the ages of shells of $M$. arenaria found in old coastal deposits in the Netherlands and answer the question of whether these are pre-Columbian or not.

\section{Materials and methods}

\section{Sampling}

Samples of $M$. arenaria were collected at five locations in the Netherlands (Fig. 1). Further sample information is given in 

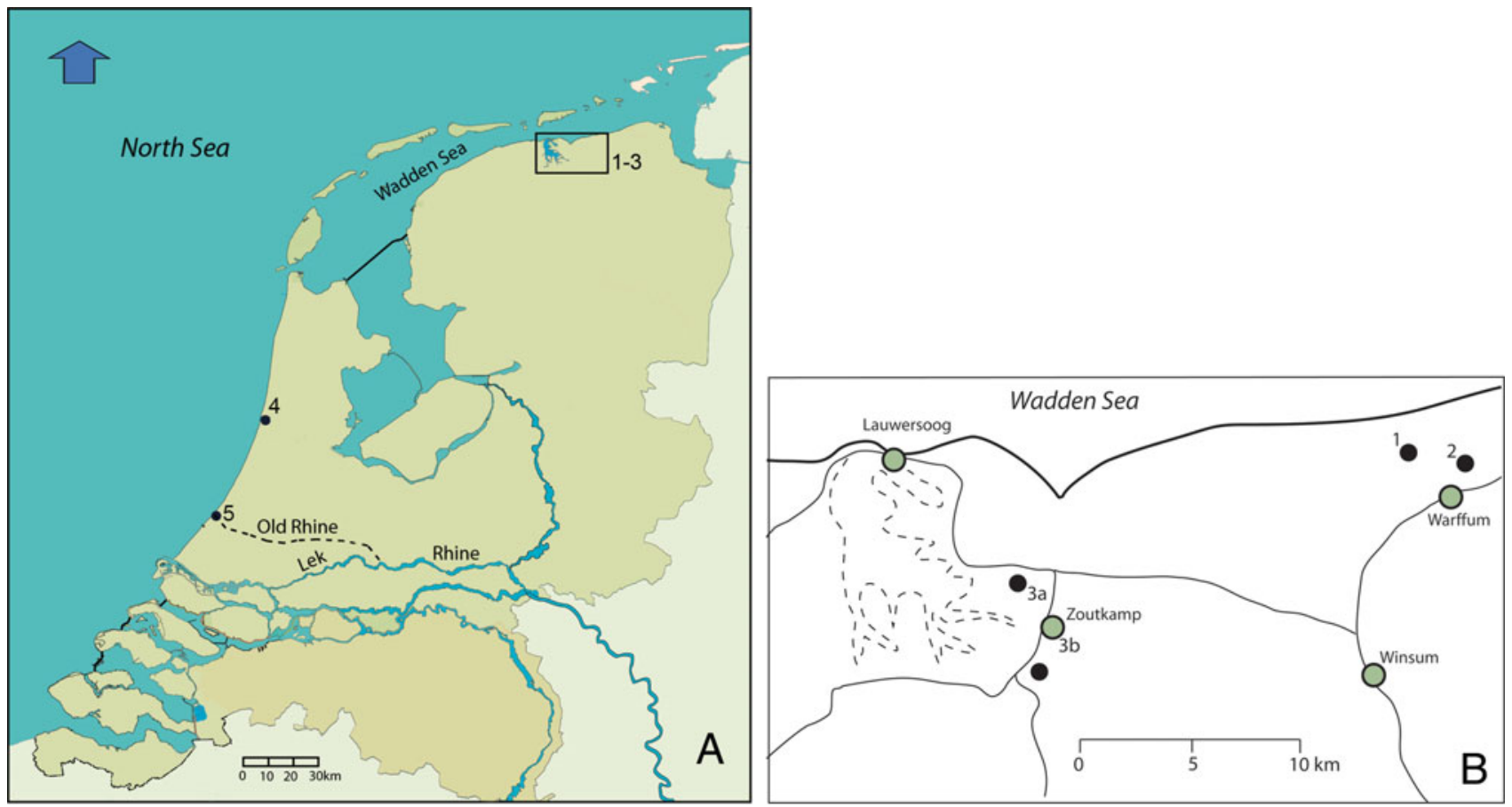

Fig. 1. A. Locations in the Netherlands where shells of Mya arenaria were found. 1-3, Province of Groningen; 4, Wijker Tunnel; 5, Katwijk aan de Rijn; B. Details of the Groningen area: solid black line indicates the sea dike; thin black line shows roads; dashed line indicates Lake Lauwersmeer. See text for further description of locations and inferred paleo-environment.

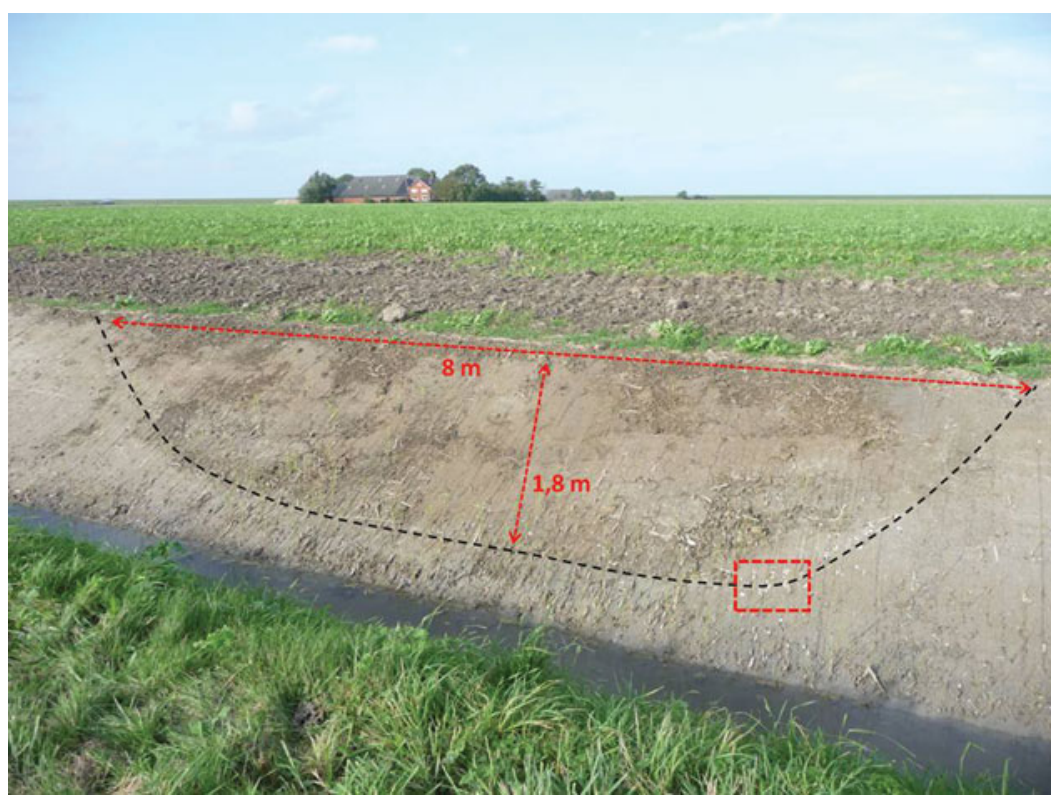

Fig. 2. Cross-section and dimensions of the filled former tidal creek at location 1, Noordpolder, province of Groningen. Rectangle shows the position of shell valves of Mya arenaria. (Photo: Dr K. Essink.)
Table 1. Location 1 is in the Noordpolder in the northern part of the province of Groningen, where shells were collected by the third author from newly dug polder ditches where the bottom of a filled former tidal creek became visible (Fig. 2). Location 2 is also in the Noordpolder; here, Mya shells were collected by the third author from a dredged polder canal. Location 3 consists of two sites northwest and southwest, respectively, of the fishing village of Zoutkamp. At location 3a (Vierhuizen), a Mya shell was collected by geologist Peter C. Vos during the construction of a natural gas pipeline (Bakker et al., 2009) just seaward of the old dike of the Lauwerszee. At location 3b (Zoutkamp-SW) a Mya shell was collected by the third author from a newly dug ditch.

Location 4 is in the western part of the Netherlands, east of IJmuiden. Here, small articulated shells of $M$. arenaria were collected by Dr T. Meijer (RGD - Geological Survey of the 


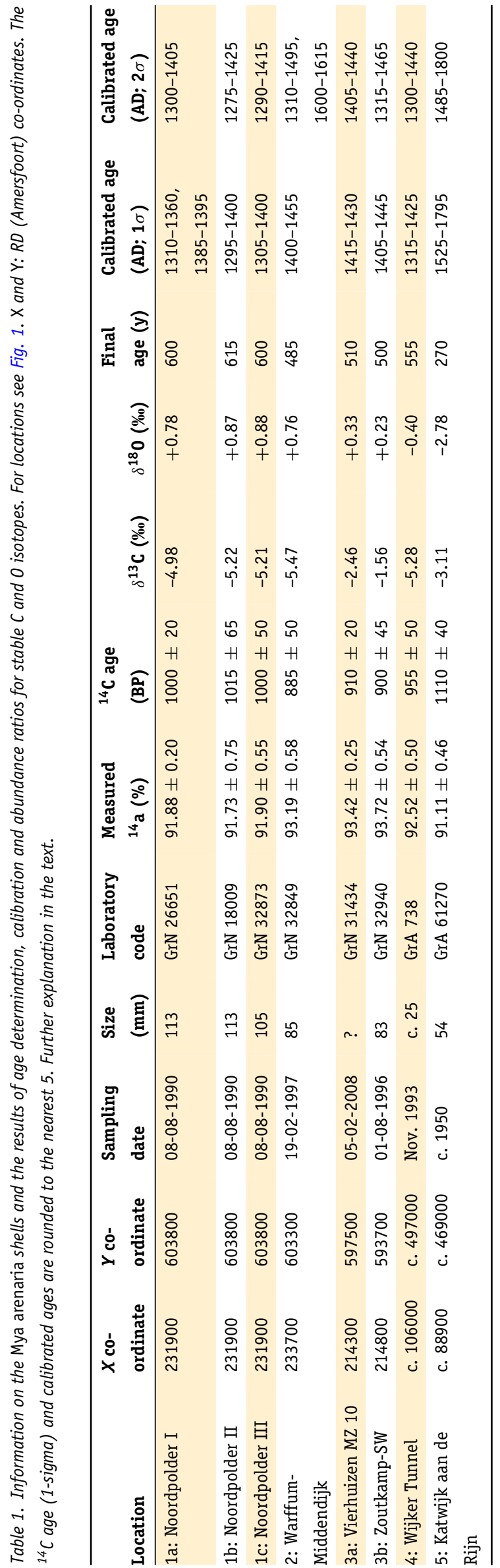

Netherlands) in 1993 in the building pit for the Wijker Tunnel, which provides an A9 motorway crossing underneath the North Sea Canal between IJmuiden and Amsterdam (Beets et al., 2003).

Also in the western part of the Netherlands, shells of $M$. arenaria were collected in the 1950s near Katwijk aan de Rijn (location 5) by the late Dr E.H.J. Warns, a non-professional resident malacologist. Part of his shell collection came into the possession of the second author in 2013. Unfortunately, the documentation regarding the find location of Mya shells in the historic estuary of the River Rhine ('Old Rhine') had been lost. Shells were partially covered with traces of clay, suggesting fairly sheltered sedimentary conditions. Among this shell material was one doublet, indicating that the specimen was found in a living position (in situ). Of this doublet one valve was used for radiocarbon age determination.

\section{Age determination and stable isotopes}

All shells were dated at the Centre for Isotope Research (CI0), Groningen. Samples received the standard chemical treatment (Mook \& Streurman, 1983). Age determination of the samples from locations $1-3$ was done using the conventional ${ }^{14} \mathrm{C}$ method (GrN-code; Mook \& Streurman, 1983). The samples from locations 4 and 5 were dated using accelerator mass spectrometry (AMS; GrA-code; Van der Plicht et al., 2000). The dates are reported in conventional radiocarbon years (BP), i.e. measured relative to the oxalic acid reference, using the conventional half-life value and including normalisation for isotope fractionation using the ${ }^{13} \mathrm{C}$ isotope (Mook \& Van der Plicht, 1999). Shell samples are subject to reservoir effects; these need to be subtracted from the conventional age before transformation to calendar years can be done (see Discussion).

In addition to ${ }^{14} \mathrm{C}$, the content of the stable isotopes ${ }^{13} \mathrm{C}$ and ${ }^{18} 0$ of the shell carbonates was also measured by isotope ratio mass spectrometry (IRMS) using the international standard VPDB as reference material (Mook, 2006).The results are expressed as delta values, i.e. deviations (in \%) of the rare/abundant isotope ratio from reference materials:

$$
\begin{aligned}
\delta^{13} \mathrm{C} & =\frac{\left[{ }^{13} \mathrm{C} /{ }^{12} \mathrm{C}\right]_{\text {sample }}}{\left[{ }^{13} \mathrm{C} /{ }^{12} \mathrm{C}\right]_{\text {reference }}}-1(\times 1000 \%) \text { and } \\
\delta^{18} 0 & =\frac{\left[{ }^{18} \mathrm{O} /{ }^{16} 0\right]_{\text {sample }}}{\left[{ }^{18} \mathrm{O} /{ }^{16} 0\right]_{\text {reference }}}-1(\times 1000 \%)
\end{aligned}
$$

\section{Results}

All relevant data and results are presented in Table 1. This table contains administrative data such as sampling locations, location co-ordinates, dates of sampling and laboratory codes. For the Mya shells analysed the length is given in millimetres when known. The shells from location 3a (Vierhuizen) were fragments, not an entire valve. Table 1 also shows the stable 
isotope ratios $\delta^{13} \mathrm{C}$ and $\delta^{18} 0$ (in \%), and the measured (notnormalised) ${ }^{14} \mathrm{C}$ activity ratio ${ }^{14} \mathrm{a}$ (in \%). The latter is defined as ${ }^{14} \mathrm{a}={ }^{14} \mathrm{~A}_{\text {sample }} /{ }^{14} \mathrm{~A}_{\text {reference, }}$ with ${ }^{14} \mathrm{~A}$ being the ${ }^{14} \mathrm{C}$ radioactivity in bequerels per gram of carbon (Mook \& Van der Plicht, 1999).

After normalisation for isotope fractionation, the ${ }^{14} \mathrm{a}$ value provides the conventional ${ }^{14} \mathrm{C}$ age (BP) with $1 \sigma$ confidence levels. This approach is valid for terrestrial samples that are in equilibrium with the atmosphere. The ocean and rivers, however, contain less ${ }^{14} \mathrm{C}$ than the atmosphere, hence shells show apparent ages: the so-called reservoir effect. This has to be subtracted from the conventional age.

For the North Sea, the reservoir effect is 400 years (e.g. Reimer et al., 2013), certainly for the time range discussed here. For rivers, the reservoir effect is significantly larger, typically 1300 years for the Rhine (Lanting \& Van der Plicht, 1998). Estuaries, where sea water and river water are mixed, obviously show intermediate values (e.g. Philippsen et al., 2013; Reimer, 2014). To obtain absolute dates for shells from the coastal area of the Netherlands, it is therefore necessary to assess the environment these bivalves were living in. This determines the recent activity of the shells during their lifetime. This is lower than the activity for contemporaneous terrestrial organisms, which translates in apparent ages: the reservoir effect.

The samples from locations 1-4 are fully marine, hence the reservoir effect can be taken as 400 years. For the Mya shell from Katwijk, a reservoir effect of 840 years applies (see Discussion). The calibrated ages ( $1 \sigma$ and $2 \sigma$ ) of the Mya shells from locations 1-4 are all older than $1492 \mathrm{AD}$. The possible age of 1600-1615 $\mathrm{AD}(2 \sigma)$ for the shell from location 2 should be disregarded because at that time the find location was agricultural land that had been endiked some centuries before. This second date range is caused by a fluctuation in the calibration curve; it has a low probability (c. $1 \%$ ) and can also mathematically be neglected. The calibrated age of the Mya shell from location 5 is much younger (1485-1800 AD; $2 \sigma$ ).

\section{Paleogeographic setting}

The Noordpolder (sampling locations 1 and 2) is a former salt marsh area in the Wadden Sea; it was endiked in 1811. The older subsoil of the Noordpolder consists of marine sediments in which the following bivalve species were found: cockle (Cerastoderma edule), blue mussel (Mytilus edulis), Baltic tellin (Macoma balthica), peppery furrow shell (Scrobicularia plana) and softshell clam (M. arenaria). Judging from the age determinations on this material (Streurman \& Van der Plicht, 2014) the subsoil of the Noordpolder and adjacent polders was an intertidal flat biotope at least between c. 700 and $1500 \mathrm{AD}$.

The find location $3 a$ (near Vierhuizen) is on the seaward side of the dike of the former Lauwerszee, an embayment of the Wadden Sea, which was endiked in 1969 (see Fig. 1). The Lauwerszee was initially formed by a series of sea intrusions in the coastal peat landscape between 600 and $800 \mathrm{AD}$, and reached its largest extension between 1000 and 1200 AD. The salt marsh area north of the find location 3a was endiked as late as 1875-1877 (Westpolder) and the area south of it was endiked in 1927 (Kerkvoogdijpolder).

The find location $3 \mathrm{~b}$ (Zoutkamp-SW) is in the Nieuwe Ruigezandsterpolder on the landward side of the dike that closed the Reitdiep estuary in 1877, after which this polder was embanked (Roeleveld, 1974; Hacquebord \& Hempenius, 1990). At both these locations intertidal flats were present for centuries, as is shown on the much detailed Beckering Chart of the Province of Groningen from 1781. Paleogeographic reconstruction maps for c. $800 \mathrm{AD}$ and c. $1150 \mathrm{AD}$ by P.C. Vos and S. de Vries also indicate intertidal flats present at the find locations 3a and 3b (see Van Beek \& Vos, 2008).

Find location 4 (Wijker Tunnel) is in the historic 0er-IJ estuary that provided outflow of the small river Vecht (a Rhine tributary) to the North Sea. When the river Vecht connected to Lake Flevo in Roman times, the mouth of the estuary silted up; a small opening may have remained until c. 1100 AD (Roep et al., 1991; Beets et al., 2003). Articulated valves of juvenile M. arenaria and Cerastoderma glaucum were found in a layer of lacustrine (Zuiderzee) clays less than $1 \mathrm{~m}$ thick (unit 7). These shells and clay are considered to indicate new brackish conditions that resulted from the north-oriented progressive opening up of the Flevo Lakes to the North Sea, first creating the tidal Almere lagoon (c. $850 \mathrm{AD}$ ) and then the brackish tidal embayment of the Zuiderzee that reached its maximum size around 1200 AD (Zagwijn, 1971; Lenselink \& Koopstra, 1994; Vos et al., 2015).

Location 5 (Katwijk aan de Rijn) is in the estuary of the historic Rhine river, which once formed the northern border (limes) of the Roman Empire (Van Dinter, 2013). From around $250 \mathrm{AD}$ onwards the river branch Lek became increasingly important for discharging via Rotterdam into the North Sea. As a consequence, the discharge through the Old Rhine towards Katwijk decreased, causing silting up of the river mouth (Henderikx, 1987; Bazelmans et al., 2011). It is assumed that this river mouth was finally closed off from the North Sea after reduction of river discharge and the building of a dam (Zwammerdam) far upstream and the effect of a storm surge in 1163 (Buisman, 1995; Van Dam, 1999; Parlevliet, 2001; Van de Ven, 2004). The closure of the river mouth was certainly not much later than 1200 AD (Van Heeringen \& Van der Valk, 1989; Van de Ven, 2004).

\section{Discussion}

\section{Marine or estuarine lifetime conditions}

In our samples we used the stable isotopes ${ }^{13} \mathrm{C}$ and ${ }^{18} 0$ as tracers for their lifetime environment. For the North Sea, shells 
typically show $\delta^{13} \mathrm{C}$ and $\delta^{18} 0$ values of c. $1.5 \%$ and c. $1.0 \%$, respectively (Mook, 1970). For the river Rhine, the $\delta^{13} \mathrm{C}$ and $\delta^{18} 0$ values are typically $-10.5 \%$ and $-9.0 \%$, respectively. For the Rhine/North Sea estuary, these values represent the end values of the mixing line for these water bodies (Mook, 1971).

The $M$. arenaria shells from locations $1-4$ show $\delta^{18} 0$ values that are considered as marine. The $\delta^{13} \mathrm{C}$ values are lower than the marine value, but the $\delta^{13} \mathrm{C}$ and $\delta^{18} 0$ values combined do not plot on the Rhine/North Sea mixing line; there is no apparent riverine component. These negative $\delta^{13} \mathrm{C}$ values are caused by complex fractionation processes, which are included in the calculation of the conventional ${ }^{14} \mathrm{C}$ age. Based on $\delta^{18} 0$, we consider these shells to be $100 \%$ marine. It is therefore justified to assume for the shells from locations 1-4 a reservoir effect of 400 years, resulting in the final ages shown in Table 1.

The $M$. arenaria shell from location 5 (Katwijk) must have lived under different conditions. The $\delta^{18} 0$ value clearly shows riverine influence. In fact, the $\delta^{13} \mathrm{C}$ and $\delta^{18} 0$ values together are exactly on the mixing line of the Rhine/North Sea estuary. For the Rhine, the recent activity ${ }^{14} \mathrm{a}_{\text {recent }}=85 \%$, corresponding to the 1300 years reservoir effect mentioned before. Taking this value and the parameters from the mixing line, the recent activity for the Katwijk shell can be calculated (see Mook, 2006). The result is ${ }^{14} \mathrm{a}_{\text {recent }}=94.24 \%$; from this the final age can be calculated as 270 years. Comparing this with the conventional ${ }^{14} \mathrm{C}$ age (BP), we see that the reservoir effect for this Mya shell is 840 years.

For our Mya shells, we know what their living conditions were: marine or estuarine. This has a significant influence on the reservoir effect that has to be taken into account. Petersen et al. (1992) only published the calibrated date; neither the ${ }^{14} \mathrm{C}$ date in $\mathrm{BP}$, nor the $\delta^{13} \mathrm{C}$ values were reported. It is also very unlikely that they measured $\delta^{18} 0$. In the Mya shells dated by Behrends et al. (2005) no stable isotope levels were assessed either. At Greifswalder Bodden the ambient salinity was about 7.3 (Behrends et al., 2005). The shells analysed by Petersen et al. (1992) originate from the coast of the Kattegat. This is also an area of reduced salinities between the North Sea/Skagerrak and Baltic Sea, although to a lesser extent than in Greifswalder Bodden. Therefore, for these Mya shells vital information is missing in relation to the extent of the reservoir effect to be taken into account.

\section{Calibration procedure}

The ages shown as final ${ }^{14} \mathrm{C}$ ages in Table 1 include the necessary reservoir effect corrections to allow for comparison with terrestrial samples. To determine the absolute age of the Mya shells, these ages need to be calibrated to calendar ages. This is done using the presently recommended calibration curve IntCal13 (Reimer et al., 2013). The calibrated age ranges are presented in calendar years $\mathrm{AD}$, at both 1-sigma and 2-sigma confidence levels (Table 1). All ages are rounded to the nearest 5.
As an example, the calibration of sample GrN-26651 (from location 1a) is shown in Fig. 3. The blue curve is the relevant part of the (terrestrial) calibration curve, established by paired dating of wood by ${ }^{14} \mathrm{C}$ and dendrochronology. The ${ }^{14} \mathrm{C}$ date (600 \pm 20 ) is plotted along the vertical ${ }^{14} \mathrm{C}$ axis. It shows a Gaussian probability distribution. The probability distribution of the calibrated date is shown in black along the horizontal axis. This distribution is obviously no longer Gaussian, as this is caused by the fluctuation ('wiggle') in the calibration curve. In fact it shows that a ${ }^{14} \mathrm{C}$ date may yield multiple solutions on the calendar. We rounded the numbers to the nearest 5, and ignored the gaps between calibrated ranges when these were not significant compared with the measurement error (see Table 1). In Table 1, the 1-sigma results are presented as 1310-1360 and 1385-1395 calAD, the 2-sigma results as $1300-1405$ calAD. For more mathematical details we refer to the literature (Van der Plicht \& Mook, 1989). The calibrated ${ }^{14} \mathrm{C}$ dates are by convention reported in calAD (Mook, 1986).

\section{Paleo-environmental setting}

For the Mya shells found in the province of Groningen (locations 1-3) the datings comply with the inferred paleogeographic setting of coastal intertidal sediments. The same holds for the shell from the Wijker Tunnel (location 4), where an estuarine environment was anticipated.

All shells from locations 1-4 clearly date as pre-Columbian. Whether these datings are really younger than those reported from Denmark is hard to say because Petersen et al. (1992) did not report on stable isotopes (see before).

The Mya shells found in the Old Rhine estuary near Katwijk (location 5) are not pre-Columbian, but younger: between 1525 and $1795 \mathrm{AD}$ (1-sigma). The stable isotope values of these shells clearly indicate that estuarine living conditions have been present. This can be explained as follows. After the closure of the mouth of the Old Rhine around $1200 \mathrm{AD}$ serious drainage problems developed in the low-lying areas behind the dune ridges north and south of the Old Rhine. Local communities began the construction of canals discharging in a northerly direction (Parlevliet, 2001; Van de Ven, 2004), but no solution to the flooding problems was achieved. In 1404, plans to re-open the river mouth were considered, but not carried out. Between 26-3-1571 and 30-11-1571, a new plan (Het Malle Gat) was realised, re-connecting the North Sea and the river Rhine via two sluice-gates. This canal, however, could not be maintained due to enduring war conditions (the Eighty Years' War against the Spanish king) (Boomgaard, 1984). Later on, a new channel was dug and opened in 1807, but locks closed the inland area off from the sea. We hypothesise that the Mya shells dated 1525-1795 AD (1-sigma) were living in the Malle Gat area around $1571 \mathrm{AD}$ under short-term estuarine conditions that may have occurred due to intrusion of saline water through the sluice-gate system. 


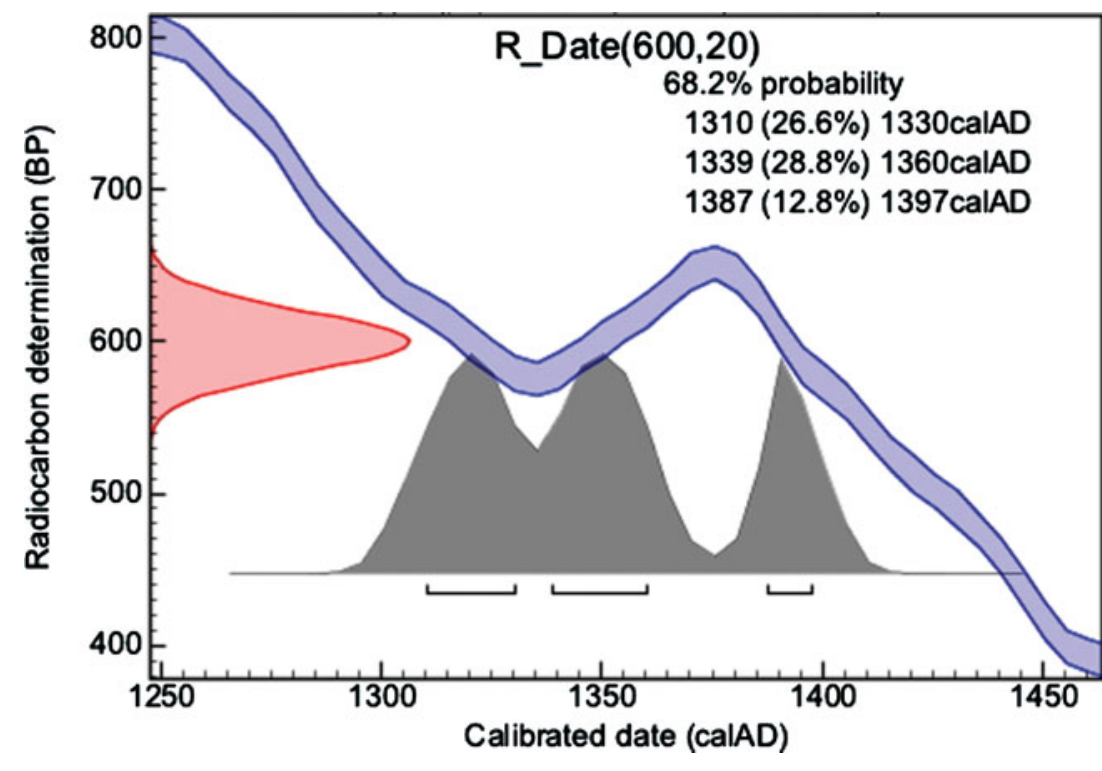

Fig. 3. Illustration of the calibration procedure applied for the Mya arenaria shell from location 1a. The IntCal13 calibration curve is shown in blue. See text for further explanation.

\section{Dispersal mechanism}

Our datings of shells of $M$. arenaria in the northern and western parts of the Netherlands are in line with the hypothesis of Viking-mediated dispersal of this species across the northern Atlantic 0cean. This hypothesis was first put forward by Petersen et al. (1992) and repeated by Behrends et al. (2005) as an explanation for their finds of pre-Columbian Mya shells in northern Denmark and the Greifswalder Bodden. The calibrated ages (with $2 \sigma$ range) of the shells found in Denmark seem to predate to some extent the ages of shells found in the Netherlands. This, however, cannot be used as a definite clue for a first arrival of North-American clams in Danish coastal waters. It has to be realised that from any site of first introduction of this species, dispersal along the shores of the North Sea would have taken place easily by means of pelagic larvae, as was illustrated for the later Northern American bivalve immigrant Ensis directus (Essink, 1985, 1986).

\section{Conclusions}

The finds of $M$. arenaria shells at four locations along the North Sea coast of the Netherlands dating to the 13th to 15th centuries $\mathrm{AD}$ provide further evidence of the re-introduction of this species from its native range in northeast America into European waters well before the discovery of America by Columbus. As a consequence, it supports the hypothesis of Vikingmediated transfer of this species from northeast America to northwest European waters as put forward by Petersen et al. (1992). The M. arenaria shell found at Katwijk (location 4) was dated 1485-1800 AD (2-sigma), with stable isotopes indicating estuarine living conditions. This indicates the existence of es- tuarine conditions long after the closing of the mouth of the old Rhine around $1200 \mathrm{AD}$. Such conditions may have occurred for some time due the digging of a temporary connection (Malle Gat) between the Old Rhine and the North Sea around 1571 AD. For a reliable dating of mollusc shells from (former) coastal and estuarine environments it is essential to also assess the stable isotopes ${ }^{13} \mathrm{C}$ and ${ }^{18} 0$ because this determines the reservoir effect that has to be taken into account.

\section{Acknowledgements}

Thanks are due to Dr R. Daan for donating to the second author the Mya shells from Katwijk aan de Rijn, collected by the late Dr E.H.J. Warns. Dating of one of these shells was made possible by the Deltares' Research Program Coastal and Estuarine Morphodynamics. Information on the historic situation at Katwijk around 1571 AD was kindly provided by Mr D. Parlevliet, Dr B. Voormolen and Dr A.W.E. Wilbers. Fig. 1 was prepared by Mr. Rob Jungcurt.

\section{Dedication}

This paper is dedicated to the memory of Prof. Dr W.G. (Wim) Mook, who passed away at the age of 83 on 24 January 2016. Wim Mook was for a long time leader of the Centre for Isotope Research (CIO) in Groningen and played a significant role in the development of radiocarbon dating.

\section{References}

Bakker, A.M., la Fèber, D.J. \& Vos, P.C., 2009. Inventariserend veldonderzoek door middel van een proefsleuf en een archeologische begeleiding op het 
gasleidingtracé Vierhuizen-Munnekezijl, gemeente De Marne. Archeologisch Rapport Oranjewoud 2008/17.

Baster, J., 1765. Natuurkundige uitspanningen, behelzende eenige waarnemingen, over sommige zeeplanten en zee-insecten, benevens derzelver zaadhuisjes en eijernesten. Tweede deel, vijfde stukje. J. Bosch (Haarlem): 53110.

Bazelmans, J., Weerts, H. \& Van der Meulen, M. (eds), 2011. Atlas van Nederland in het Holoceen. Bert Bakker (Amsterdam): $94 \mathrm{pp}$.

Beets, D.J., De Groot, T.A.M. \& Davies, H.A., 2003. Holocene tidal back-barrier development at decelerating sea-level rise: a 5 millennia record, exposed in the western Netherlands. Sedimentary Geology 158: 117-144.

Behrends, B., Hertweck, G., Liebezeit, G. \& Goodfriend, G., 2005. Earliest Holocene occurrence of the soft-shell clam, Mya arenaria, in the Greifswalder Bodden, Southern Baltic. Marine Geology 216: 79-82.

Bernard, F.R., 1979. Identification of the living Mya (Bivalvia: Myoida). Venus 38: 185-204.

Boomgaard, J.E.A., 1984. De eerste doorgraving van de duinen bij Katwijk. De aanleg van duikers en plannen voor een uitwateringssluis in de periode 14041629. In: De uitwateringssluizen van Katwijk 1404-1984. Hoogheemraadschap van Rijnland (Leiden): 9-17.

Buisman, J., 1995. Duizend jaar weer, wind en water in de lage landen. Deel 1. Tot 1300. Van Wijnen (Franeker): $656 \mathrm{pp}$.

Dupont, C., Schulting, R. \& Tresset, A., 2007. Prehistoric shell middens along the French Atlantic façade: the use of marine and terrestrial resources in the diets of coastal human populations. In: Milner, N., Craig, 0. \& Bailey, G. (eds): Shell middens in Atlantic Europe. Oxbow Books (0xford): 123135.

Dupont, C., Tresset, A., Desse-Berset, N., Gruet, Y., Marchand, G. \& Schulting, $\boldsymbol{R} ., 2009$. Harvesting the seashores in the Late Mesolithic of Northwestern Europe: A View From Brittany. Journal of World Prehistory 22: 93-111.

Essink, K., 1985. On the occurrence of the American jack-knife clam Ensis directus (Conrad, 1843) (Bivalvia, Cultellidae) in the Dutch Wadden Sea. Basteria 49: 73-80.

Essink, K., 1986. Note on the distribution of the American jack-knife clam Ensis directus (Conrad, 1843) in N.W. Europe (Bivalvia, Cultellidae). Basteria 50: 33-34.

Hacquebord, L. \& Hempenius, A.L., 1990. Groninger dijken op deltahoogte. Wolters-Noordhoff/Egbert Forsten (Groningen): 103 pp.

Henderikx, P.A., 1987. De beneden-delta van Rijn en Maas. Landschap en bewoning van de Romeinse tijd tot ca. 1000. Verloren (Hilversum): $174 \mathrm{pp}$.

Hessland, I., 1946. On the quaternary Mya period in Europe. Arkiv för Zoologi 37A: 1-51.

Lanting, J.N. \& Van der Plicht, J., 1998. Reservoir effects and apparent ${ }^{14} \mathrm{C}$ ages. Journal of Irish Archaeology 9: 151-165.

Lasota, R., Hummel, H. \& Wolowicz, M., 2004. Genetic diversity of European populations of the invasive soft-shell clam Mya arenaria (Bivalvia). Journal of the Marine Biological Association of the UK 84: 1051-1056.

Lenselink, C. \& Koopstra, R., 1994. Ontwikkelingen in het Zuiderzeegebied: van Meer Flevo, via Almere lagune, tot Zuiderzee. In: Rappol, M. \& Soonius, C.M. (eds): In de bodem van Noord-Holland,geologie en archeologie. Lingua Terrae Books (Amsterdam): 129-140.

Mook, W.G., 1970. Stabiele isotopen van koolstof en zuurstof in water en kalk. Geologie en Mijnbouw 49: 397-404.
Mook, W.G., 1971. Paleotemperatures and chlorinities from stable carbon and oxygen isotopes in shell carbonate. Palaeogeography, Palaeoclimatology, Palaeoecology 9: 245-263.

Mook, W.G., 1986. Business meeting, 12th International Radiocarbon Conference. Radiocarbon 28: 799.

Mook, W.G., 2006. Introduction to isotope hydrology. Stable and radioactive isotopes of hydrogen, oxygen and carbon. Taylor \& Francis (London): $226 \mathrm{pp}$.

Mook, W.G. \& Streurman, H.J., 1983. Physical and chemical aspects of radiocarbon dating. In: Mook, W.G. \& Waterbolk H.Tj. (eds): Proceedings of the Groningen Symposium $14 \mathrm{C}$ and Archaeology. PACT Publication 8: 31-55.

Mook, W.G. \& Van der Plicht, J., 1999. Reporting ${ }^{14} \mathrm{C}$ activities and concentrations. Radiocarbon 41: 227-239.

Mougne, C., Dupont, C., Giazzon, D. \& Quesnel, L., 2014. Shellfish from the Bronze Age Site of Clos des Châtaigniers (Mathieu, Normandy, France). Internet Archaeology. doi:10.11141/ia.37.5.

Parlevliet, D., 2001. De Rijnmond verstopt. Holland, Historisch Tijdschrift 33: 3-16.

Petersen, K.S., Rasmussen, K.L., Heinemeier, J. \& Rudd, N., 1992. Clams before Columbus? Nature 359: 679.

Philippsen, B., Olsen, J., Lewis, J.P., Rasmussen, P., Ryves, D.B. \& Knudsen, K.L., 2013. Mid- to late-Holocene reservoir age variability and isotope based palaeoenvironmental reconstruction in the Limfjord, Denmark. The Holocene 23: 1017-1027.

Reimer, P.J., 2014. Marine or estuarine radiocarbon reservoir corrections for mollusks? A case study from a medieval site in the south of England. Journal of Archaeological Science 49: 142-146.

Reimer, P.J., Bard, B., Bayliss, A., Beck, J.W., Blackwell, P.G., Bronk Ramsey, C., Buck, C.E., Edwards, R.L., Friedrich, M., Grootes, P.M., Guilderson, T.P., Haflidason, H., Hajdas, I., Hatté, C., Heaton, T.J., Hoffmann, D.L., Hogg, A.G., Hughen, K.A., Kaiser, K.F., Kromer, B., Manning, S.W., Niu, M., Reimer, R.W., Richards, D.A., Scott, E.M., Southon, J.R., Staff, R.A., Turney, C.S.M. \& Van der Plicht, J., 2013. IntCal13 and Marine13 radiocarbon age calibration curves 0-50,000 years cal BP. Radiocarbon 55: 1869-1887.

Roeleveld, W., 1974. The Groningen coastal area: a study in Holocene geology and low-land physical geography. $\mathrm{PhD}$ thesis, Vrije Universiteit Amsterdam: $252 \mathrm{pp}$.

Roep, Th. B., Van der Valk, L. \& Beets, D.J., 1991. Strandwallen en zeegaten langs de Hollandse kust. Grondboor \& Hamer 45 (5/6): 115-124.

Rondeletius, G., 1554. Libri de Piscibus marinis, in quibus verae Piscium effigies expressae sunt: quae in tota Piscium historia contineantur, indicat Elenchus pagina nona \& decima. Matthiam Bonhomme (Lyon).

Strasser, M., 1999. Mya arenaria - an ancient invader of the North Sea coast. Helgoländer Meeresuntersuchungen 52: 309-324.

Streurman, H.J. \& Van der Plicht, J., 2014. Het insula ten Noorden van Warffum. Een bijdrage van de koolstofisotopen. Historisch Jaarboek Groningen 2014. Koninklijke Van Gorkum (Assen): 6-15.

Van Beek, J.L. \& Vos, P.C., 2008. Regio Groningen. Gemeenten De Marne, Winsum, Bedum, Ten Boer, Loppersum, Eemsmond, Appingedam en Delfzijl. Archeologische verwachtingskaart en beleidsadvieskaart. RAAP-Rapport 1732, kaartbijlagen $7 \& 8$.

Van Benthem Jutting, W.S.S., 1942. On the fossil occurrence of Mya arenaria L. in the Netherlands. Basteria 7: 1-40. 
Van Dam, $\boldsymbol{P}_{\text {., }}$ 1999. Stuivend zand en stormende golven De vorming van de Hollandse kust in de Middeleeuwen. Madoc 13: 224234.

Van de Ven, G.P. (ed.), 2004. Man made lowlands. History of water management and land reclamation in the Netherlands, 4th revised edn. Matrijs (Utrecht): $432 \mathrm{pp}$.

Van der Plicht, J. \& Mook, W.G., 1989. Calibration of Radiocarbon ages by computer. Radiocarbon 31, 805-816.

Van der Plicht, J., Wijma, S., Aerts, A.T., Pertuisot, M.H. \& Meijer, H.A.J., 2000. The Groningen AMS facility: status report. Nuclear Instruments and Methods B172: 58-65.
Van Dinter, M., 2013. The Roman Limes in the Netherlands: how a delta landscape determined the location of the military structures. Netherlands Journal of Geosciences - Geologie en Mijnbouw 92: 11-32.

Van Heeringen, R.M. \& Van der Valk, L., 1989. De mond van de Oude Rijn komt in beweging. IJzertijdvondsten uit het Katwijkse duingebied. Westerheem 38: 198-203.

Vos, P.C., De Koning, J. \& Van Eerden, R., 2015. Landscape history of the Oer-IJ tidal system, Noord-Holland (the Netherlands). Netherlands Journal of Geosciences 94: 295-332.

Zagwijn, W.H., 1971. De ontwikkeling van het 'Oer-IJ' estuarium en zijn omgeving. Westerheem 20: 11-18. 